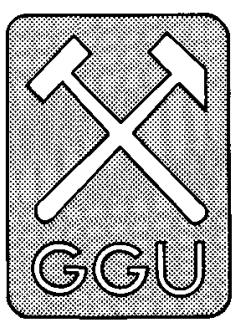

\title{
1990 - a year of change in hydrocarbon- geological activities at the Geological Survey of Greenland
}

\author{
T. C. R. Pulvertaft
}

The background for the Geological Survey of Greenland's (GGU's) hydrocarbon-geological activities was briefly outlined in the Report of Activities for 1989 (Stemmerik et al., 1990a). In that report it was intimated that a shift of emphasis in hydrocarbon-geological activities was under way, not only from onshore to offshore but also from East to West Greenland (Fig. 1). 1990 saw this shift take more concrete form. Thus field work in East Greenland was limited to minor projects that focus on diagenesis and reservoir properties of siliciclastic sediments. All other projects onshore East Greenland have reached or are entering into final report stage. A full report on the results of GGU's NorthEast Greenland hydrocarbon geology project has been presented both to an international forum (conference on 'Arctic geology and petroleum potential', Troms $\varnothing$, August 1990) and to the Mineral Resources Administration for Greenland (MRA) (Stemmerik et al., 1990b,

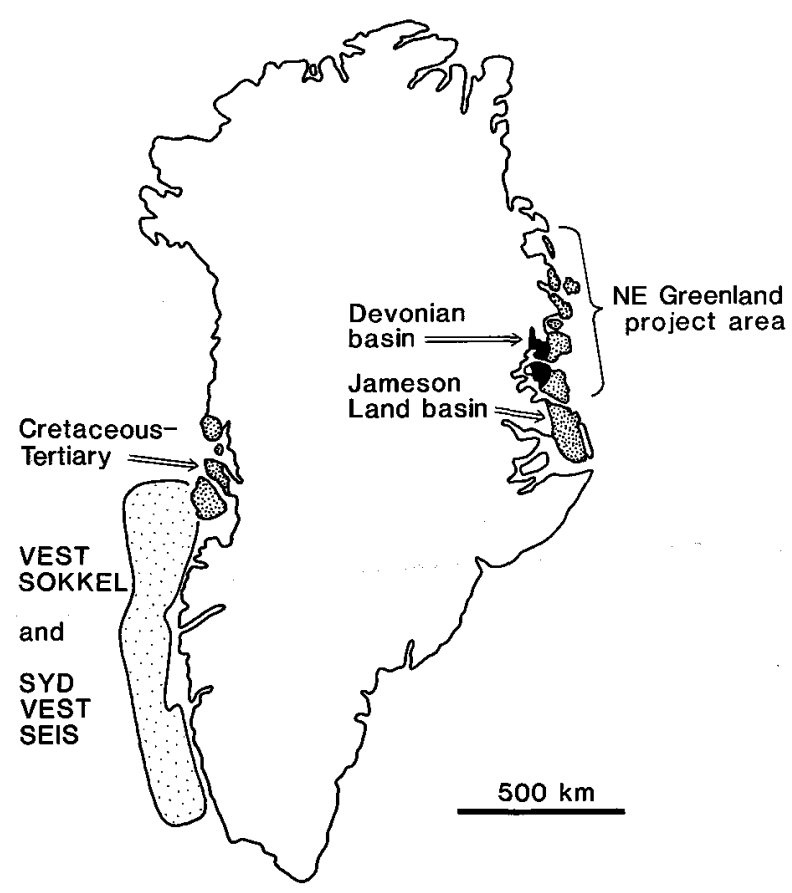

Fig. 1. Map showing areas of hydrocarbon-geological activity in Greenland in 1990. in press). Two other projects related to hydrocarbon exploration, one in the Devonian basin of North-East Greenland and one in the Upper Triassic - Lower Jurassic in Jameson Land, terminate at the end of the year. Furthermore, industry exploration in East Greenland was brought to a halt in 1990 when ARCO Greenland, the operating company in Jameson Land, announced that it would relinquish its concession at the end of the year. This decision however increases rather than diminishes GGU's immediate activity in the Jameson Land basin, as ARCO is handing over copies of all its data from Jameson Land, including $1798 \mathrm{~km}$ of reflection seismic data, to the MRA. These data, to which GGU has free access, together with GGU's own data collected in previous years, form the basis of an independent GGU evaluation of the basin and of requirements for further investigations. An exploration report dealing with the prospectivity of the basin was delivered to the MRA at the end of the year.

Articles summarising the results of the North-East Greenland hydrocarbon-geological project and the Devonian basin project are given by Stemmerik et al. (1991) and Larsen \& Olsen (1991). Some of the most important results of work in the Triassic-Jurassic (Rhaetian-Sinemurian) in Jameson Land are to be found in Dam \& Christiansen (1990) and Dam (in review).

\section{Offshore West Greenland}

In West Greenland the offshore seismic acquisition project SYD VEST SEIS, announced in Report of Activities 1989, was successfully carried out. A total of 3285 line $\mathrm{km}$ was shot, and the data are now being processed by the contractor, Halliburton Geophysical Services, Inc., in Calgary. More details about the project and the 1990 cruise are given in Chalmers \& DahlJensen (1991).

Another initiative offshore West Greenland, the reprocessing of $c .2670 \mathrm{~km}$ of the reflection seismic data from the Labrador Sea acquired by the German Bundesanstalt für Geowissenschaften und Rohstoffe (BGR) in 1977 , is proceeding according to plan. All the reprocessed lines have now been delivered by the contractor, 
Prakla Seismos AG, and interpretation is in progress. The interpretation of $275 \mathrm{~km}$ of one line, which were reprocessed as a test, is complete. This has shown that rotated faults blocks interpreted as continental crust can be traced away from the shelf as far as $125 \mathrm{~km}$ from the foot of the continental rise. Thick sedimentary sequences rest on the fault blocks. This is an area hitherto supposed to be underlain by oceanic crust of Late Cretaceous age. These results show that deep water areas off southern West Greenland must be taken into account when assessing the petroleum potential of West Greenland (Chalmers, in press).

Reinterpretation of industry data from the $1970 \mathrm{~s}$ (Project VEST SOKKEL - see Chalmers, 1990) continues. Phase I has been completed as far as interpretation is concerned, map-drawing is almost complete, and a report is in preparation. A general reassessment of the petroleum prospectivity of the West Greenland area based partially on these results was presented to an international forum at the conference on 'Arctic geology and petroleum potential' held in Troms $\varnothing$ in August 1990 (Chalmers \& Pulvertaft in press). The conclusions drawn were that:

(1) None of the wells drilled in the 1970s penetrated a structure that is unambiguously capable of trapping hydrocarbons.

(2) Considerable thicknesses of sediment not tested by drilling exist at depths at which source rocks within them would be mature for oil generation.

(3) A number of new areas have been identified which could contain structures capable of generating and trapping hydrocarbons.

\section{Onshore West Greenland}

Onshore West Greenland is probably not a prospective area in itself, but the Upper Cretaceous - Lower Tertiary sediments exposed on Disko, Nûgssuaq and Svartenhuk Halv $\varnothing\left(69^{\circ}-72^{\circ} \mathrm{N}\right)$ can provide clues to the interpretation of offshore geology, particularly as they include the only marine sediments of this age exposed anywhere in the entire Labrador Sea - Baffin Bay region. For this reason general oil-geological investigations were carried out in these sediments both by GGU and by industry in the $1970 \mathrm{~s}$. Naturally, with a renewed interest in the offshore areas, there is a need for more detailed knowledge of the relevant onshore geology, in particular for a more precise palynostratigraphy of the sediments and an up-to-date study of potential source rocks and the factors leading to their distribution and lateral variation. GGU is therefore planning a twoseason campaign in the Disko-Nûgssuaq-Svartenhuk
Halv $\emptyset$ area of West Greenland as part of the Disko Bugt project (Kalsbeek, 1990), to start in 1991. As a prologue a two-man group visited the area in 1990 to identify targets for particular study and to sample representative sections for preliminary palynological and source rock studies.

\section{Offshore East Greenland}

The industry-financed seismic reconnaissance project KANUMAS (for background see Larsen \& Pulvertaft, 1990) was unable to start field operations in 1990 because of difficulties in procuring a vessel that was both equipped for seismic surveying and had the very high ice class required for operations offshore North-East Greenland. However, planning for field operations in this area in 1991 is now well under way. An article summarising present knowledge about the entire East Greenland shelf was published in Volume L of the Geology of North America series (Larsen, 1990).

\section{GHEXIS - a new information service for industry}

In the spring of 1990 an ad hoc working group was nominated by the Chairman of the Greenland Home Rule Authority and the Danish Minister for Energy with the task of making recommendations for a new strategy for exploration and utilisation of mineral resources in Greenland. In response to the recommendations of this group, GGU has introduced a new information service for the oil industry which is known as GHEXIS ( $G$ reenland Hydrocarbon $E X$ ploration Information Service). This will provide industry with a biannual newsletter together with publications lists, information about databases, and any other hydrocarbongeological information of interest and assistance to exploration managers and other planners. The first GHEXIS Newsletter was sent out in November 1990.

\section{References}

Chalmers, J. A. 1990: Re-evaluation of the geology of the southern West Greenland shelf - Project VEST SOKKEL. Rapp. Grønlands geol. Unders. 148, 29-32.

Chalmers, J. A. in press: New evidence on the structure of the Labrador Sea/Greenland continental margin. J. geol. Soc. London 147.

Chalmers, J. A. \& Dahl-Jensen, T. 1991: Project SYD VEST SEIS - $3285 \mathrm{~km}$ of multichannel seismic data acquired on the southern West Greenland shelf. Rapp. Grønlands geol. Unders. 152 (this volume).

Chalmers, J. A. \& Pulvertaft, T. C. R. in press: The southern West Greenland continental shelf - was petroleum explora- 
tion abandoned prematurely? In Vorren, T, O. et al. (ed.) Arctic geology and petroleum potential. Amsterdam: Elsevier for Norwegian Petroleum Society.

Dam, G. in review: Wave- and storm-dominated lacustrine deltas, Kap Stewart Formation (Rhaetian-Sinemurian), Jameson Land, East Greenland. Sediment. Geol.

Dam, G. \& Christiansen, G. 1990: Organic geochemistry and source potential of the lacustrine shales of the Upper Triassic - Lower Jurassic Kap Stewart Formation, East Greenland. Marine Petrol. Geol. 7, 428-443.

Kalsbeek, F. 1990: Disko Bugt Project, central West Greenland. Rapp. Grønlands geol. Unders. 148, 21-24.

Larsen, H. C. 1990: The East Greenland Shelf. In Grantz, A., Johnson, [G.] L. \& Sweeney, J. F. (ed.) The geology of North America, L. The Arctic Ocean region, 185-210. Boulder, Colorado: Geological Society of America.

Larsen, H. C. \& Pulvertaft, T. C. R. 1990: Regional marine seismic reconnaissance. Rapp. Grønlands geol. Unders. 148, 32-34.

Larsen, P.-H. \& Olsen, H. 1991: The Devonian basin project, North-East Greenland - a summary. Rapp. Grønlands geol. Unders. 152 (this volume).
Stemmerik, L., Pulvertaft, T. C. R. \& Larsen, H. C. 1990a: Current activities in the field of hydrocarbon geology. Rapp. Grønlands geol. Unders. 148, 24-29.

Stemmerik, L., Christiansen, F. G. \& Piasecki, S. 1990b: Oliepotentialet i Østgrønland nord for $72^{\circ} \mathrm{N}$. Unpubl. GGU rep. submitted to Mineral Resources Administration for Greenland, 31 pp. +27 appendices.

Stemmerik, L., Christiansen, F. G. \& Piasecki, S. 1991: Evaluation of the hydrocarbon potential onshore North-East Greenland $\left(72^{\circ}-75^{\circ} \mathrm{N}\right)$. Rapp. Grønlands geol. Unders. 152 (this volume).

Stemmerik, L., Christiansen, F. G., Piasecki, S., Jordt, B., Marcussen, C. \& Nøhr-Hansen, H. in press: Depositional history and petroleum geology of the Carboniferous to Cretaceous sediments in the northern part of East Greenland. In Vorren, T. O, et al. (ed.) Arctic geology and petroleum potential. Amsterdam: Elsevier for Norwegian Petroleum Society.

T. C. R. P., Geological Survey of Greenland, Copenhagen.

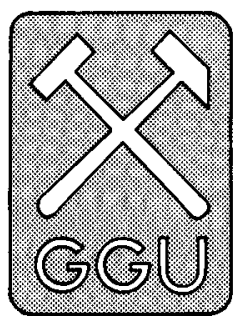

\section{Evaluation of the hydrocarbon potential onshore North-East Greenland $\left(72^{\circ}-75^{\circ} \mathrm{N}\right)$}

\author{
Lars Stemmerik, Flemming G. Christiansen \\ and Stefan Piasecki
}

In 1986 the Geological Survey of Greenland (GGU) initiated a major field and laboratory programme in the onshore areas of North-East Greenland in order to evaluate the petroleum potential and provide basic petroleum geological information for future exploration in the region (Fig. 1).

The main petroleum geological interest in North-East Greenland is focussed on the 5-6 km thick Carboniferous-Cretaceous succession (Fig. 2). These deposits have previously only been superficially studied with the exception of the Jurassic - Lower Cretaceous succession (Surlyk, 1977, 1978).

GGU's programme included detailed dating of the Carboniferous and Cretaceous sediments, identification and quantification of potential source rocks, mapping of the regional maturity pattern, and sedimentological studies of the Carboniferous and Permian sediments. The main results, summarised below, are published in an overview paper by Stemmerik et al. (in press) and in a number of more detailed contributions (Christiansen et al., 1990a, in press; Piasecki et al., 1990; Piasecki \& Stemmerik, in press; Rasmussen et al., 1990; Stemmerik et al., 1991a, b). Furthermore, a number of internal reports dealing with these topics are available from GGU (e.g. Christiansen, 1990; Christiansen \& Boserup, 1990; Christiansen et al., 1990b, c; Vigran, 1990a, b).

\section{Potential source rocks}

Potential source rocks (i.e. rocks that could generate hydrocarbons if suitably mature) occur at three stratigraphic levels in the area investigated (Fig. 2). These sediments are:

(1) Westphalian (Upper Carboniferous) lacustrine shales; 